\author{
Ryszard Barczyk \\ Uniwersytet Ekonomiczny w Poznaniu \\ e-mail: ryszard.barczyk@ue.poznan.pl
}

MORFOLOGIA CYKLI KONIUNKTURALNYCH

I CYKLI BANKOWYCH W GOSPODARCE POLSKIEJ

W LATACH 2000-2017

\title{
MORPHOLOGY OF BUSINESS CYCLES \\ AND BANK CYCLES IN POLISH ECONOMY \\ IN THE YEARS 2000-2017
}

DOI: $10.15611 /$ pn.2018.509.03

JEL Classification: E32

Streszczenie: $\mathrm{W}$ wysoko rozwiniętych gospodarkach rynkowych nasiliły się relacje między sferą realną i nominalną, tj. zwiększyły się m.in. związki między ogólnogospodarczymi cyklami koniunkturalnymi a wahaniami występującymi w sektorze bankowym. Celem pracy jest analiza morfologii i wzajemnego oddziaływania wahań, generowanych przez bank centralny i banki komercyjne, na ogólnogospodarczy cykl koniunkturalny w gospodarce polskiej w latach 2000-2017. Opracowanie ma charakter teoretyczno-empiryczny i składa się z dwóch części. W pierwszej sformułowano hipotezy dotyczące analizowanych zależności, w drugiej przeanalizowano cechy morfologiczne badanych cykli. Z analiz wynika, że w badanym okresie w gospodarce polskiej występowały sprzyjające warunki do powstawania cykli w sektorze bankowym. Ich morfologia była zbliżona do budowy i właściwości ogólnogospodarczych cykli koniunkturalnych.

Słowa kluczowe: cykl koniunkturalny, sektor bankowy, bank centralny, banki komercyjne, polityka pieniężna, przedsiębiorstwa, gospodarstwa domowe.

Summary: Apart from the general economic cycles, market economies are characterized by their specific cycles which also include bank cycles. Fluctuations whose sequence over time are created by credit bank are absolute or/and relative changes in the activity of banks, manifested in the form of oscillations in the supply of money, bank credits granted for investment or consumption purposes. The aim of this article is to analyze the morphology and influence of general business cycles on changes of activity of central and commercial banks and returnable relation between bank activity and business cycles. The paper consists of two parts. The first one presents theoretical hypothesis connected with analyzed relations. The second part contains the results of empirical analysis of morphology of analysed cycles which were estimated in the Polish economy.

Keywords: business cycle, banking sector, central bank, commercial banks, monetary policy, enterprices, households. 


\section{Wstęp}

W ostatnich latach, zwłaszcza po wybuchu światowego kryzysu finansowego, w gospodarstwach rynkowych wzrosło znaczenie zależności między zjawiskami i procesami występującymi w sferze realnej gospodarki a zmianami w sferze nominalnej. Oznacza to, że zwiększyła się m.in. siła związków między krótko- i średniookresowymi, ogólnogospodarczymi wahaniami koniunkturalnymi oraz dynamiką działalności banku centralnego i banków komercyjnych. Wyjaśnienie tych zależności ma znaczenie poznawcze, a głównie praktyczne w aspekcie prowadzonej polityki stabilizacji makroekonomicznej.

Celem pracy jest analiza morfologii i współwystępowania cykli generowanych przez bank centralny i banki komercyjne oraz ogólnogospodarczego cyklu koniunkturalnego, występujących w gospodarce polskiej w latach 2000-2017². Praca ma charakter teoretyczno-empiryczny i składa się z dwóch części. W pierwszej zostaną sformułowane hipotezy dotyczące badanych związków, w drugiej przeanalizowane cechy morfologiczne wyodrębnionych cykli i zależności między nimi. Analizy empiryczne będą prowadzone dla gospodarki polskiej w okresie od I kwartału 2000 do III kwartału 2017, a przedmiotem szczegółowych analiz będzie produkt krajowy brutto, spożycie indywidualne gospodarstw domowych oraz nakłady brutto na środki trwałe, oszacowane w cenach stałych, oraz poszczególne rodzaje kredytów, udzielanych przedsiębiorstwom i gospodarstwom domowym na cele inwestycyjne lub konsumpcyjne, a także dynamika podaży agregatów pieniężnych $\mathrm{M}_{1}$ i $\mathrm{M}_{2}$. Dobór okresu analizy był uwarunkowany dostępem do porównywalnych danych empirycznych, publikowanych przez Główny Urząd Statystyczny i Narodowy Bank Polski.

\section{Hipotetyczne zależności między cyklem koniunkturalnym a cyklami generowanymi przez sektor bankowy}

W gospodarkach rynkowych obok ogólnogospodarczych cykli koniunkturalnych występują także cykle specyficzne, generowane przez sektor bankowy. Fluktuacje, których sekwencja w czasie tworzy te cykle, to absolutne lub względne zmiany w działalności banku centralnego i banków komercyjnych. Ich formą są oscylacje występujące nie tylko w kształtowaniu stóp procentowych, podaży pieniądza, lecz także kredytów przyznawanych przez banki komercyjne i wykorzystywanych na cele inwestycyjne lub konsumpcyjne. Geneza cykli bankowych wynika z funkcjonowania tego sektora, $\mathrm{tj}$. $\mathrm{z}$ akceptowanych celów i narzędzi stabilizacyjnej polityki pieniężnej banku centralnego oraz $\mathrm{z}$ realizowanych operacji aktywnych krajowych

1 W przypadku występowania cykli sektora bankowego i ogólnogospodarczego cyklu koniunkturalnego będzie chodziło także o określenie, w jakim stopniu polityka pieniężna ma charakter procykliczny, a w jakim stopniu antycykliczny [Małecki 2014, s. 27-54]. 
i zagranicznych banków komercyjnych. Obok czynników endogenicznych, występujących wewnątrz sektora bankowego, ważną rolę w procesie kształtowania tych cykli odgrywają czynniki egzogeniczne, będące konsekwencją zmian w otoczeniu makroekonomicznym, związanych z krótko- i średniookresowymi zmianami ogólnogospodarczej aktywności gospodarczej [Barczyk 2014, s. 261-277]. Jednocześnie występowanie cykli w sektorze bankowym jest czynnikiem modyfikującym morfologię, tj. elementy budowy i właściwości ogólnogospodarczych cykli koniunkturalnych.

\subsection{Geneza cykli w sektorze bankowym $i$ ich rola w ksztaltowaniu ogólnogospodarczego cyklu koniunkturalnego}

Powstanie cykli w sektorze bankowym jest konsekwencją prowadzenia stabilizacyjnej polityki pieniężnej. Głównym podmiotem formułującym cele, stosującym określone instrumenty oraz oceniającym skuteczność poszczególnych narzędzi jest w gospodarce rynkowej bank centralny. W procesie realizacji tej polityki biorą także udział banki komercyjne, które - pełniąc określone funkcje aktywne, pasywne i pośredniczące - stają się wykonawcami polityki banku centralnego [Jaworski i in. 1998, s. 63].

W warunkach współczesnych, tj. w okresie dominacji monetaryzmu, przyjmuje się, że głównym celem polityki pieniężnej banku centralnego jest utrzymywanie stabilnej wartości pieniądza [Kaźmierczak 2012, s. 125-127]. Zamiar ten jest osiągany przez wspieranie polityki gospodarczej, realizowanej w danym kraju. Można stwierdzić, że głównym zadaniem stawianym przed instrumentami polityki pieniężnej jest wpływanie na sferę nominalną gospodarki w taki sposób, aby osiągać określone wielkości makroekonomiczne ze sfery realnej, np. szybki i zrównoważony wzrost gospodarczy, wysoki poziom zatrudnienia [Jarchow 1995, s. 100-101]. Cel antyinflacyjny jest osiągany poprzez realizację restrykcyjnej polityki pieniężnej. Polega ona na ograniczaniu podaży pieniądza na rynku. W ramach polityki antyinflacyjnej, zgodnie z tezami ekonomii keynesowskiej, przyjmuje się, że w tych warunkach powinien wystąpić wzrost ceny pieniądza, czyli wzrost stóp procentowych. Efektem tych działań powinno być zmniejszenie popytu na kredyt, a tym samym ograniczenie kredytów udzielanych przez banki komercyjne na cele inwestycyjne i dobra konsumpcyjne. Jeżeli w ramach działań stabilizacyjnych polityka pieniężna dąży także do realizacji działań antycyklicznych, tj. szybkiego i zrównoważonego wzrostu gospodarczego, to można stwierdzić, że polityka banku centralnego w fazie wysokiej dynamiki wzrostu powinna także mieć charakter restrykcyjny. Polityka taka, prowadzona w okresie gdy poszczególne czynniki wytwórcze są wykorzystywane w coraz wyższym stopniu, ma za zadanie chłodzenie gospodarki po to, aby nie dopuścić do jej przegrzania. Działania te powinny doprowadzić do spadku płynności banków komercyjnych wskutek zmniejszenia podaży pieniądza banku centralnego lub wzrostu jego ceny (stóp procentowych), a tym samym do spadku liczby i wielkości udzielanych kredytów. Ograniczenie fazy dynamiki działalności 
sektora bankowego może spowodować hamowanie szybkości wzrostu popytu rynkowego, zwłaszcza na dobra inwestycyjne i osłabienie dynamiki poprawy ogólnogospodarczej aktywności. Może ono także doprowadzić do zmniejszenia dynamiki wzrostu zatrudnienia i wzrostu bezrobocia.

Pewne trudności w realizacji restrykcyjnej polityki pieniężnej mogą wystąpić w fazie niskiej dynamiki wzrostu. W tych warunkach bank centralny, a wraz z nim banki komercyjne będą wykazywały skłonność do prowadzenia polityki ekspansywnej, której celem będzie ograniczenie negatywnych skutków recesji. Polityka ta będzie miała za zadanie hamowanie szybkości spadku aktywności makroekonomicznej. Wzrost podaży pieniądza kredytowego banku centralnego na rynku może powodować hamowanie dynamiki spadku popytu na środki inwestycyjne i na dobra konsumpcyjne, pełniejsze wykorzystanie zdolności produkcyjnych kapitału stałego oraz wzrost zatrudnienia. Konsekwencją tak prowadzonej polityki pieniężnej może być nie tylko ograniczenie dynamiki wzrostu cen, lecz także - jeśli wystąpią sprzyjające czynniki zewnętrzne - wzrost oczekiwań inflacyjnych i pojawienie się stagflacji.

Polityka pieniężna banku centralnego, prowadzona w warunkach zmian aktywności gospodarczej, będzie tworzyła sprzyjające warunki do generowania krótko- i średniookresowych wahań w działalności całego sektora bankowego. Przebieg tych oscylacji będzie widoczny w zmianach podaży pieniądza na rynku czy zmianach stóp procentowych, a także dynamiki udzielanych kredytów inwestycyjnych czy konsumpcyjnych. Ich kształtowanie i cechy morfologiczne, a tym samym przebieg faz cykli sektora bankowego będą zależały od konsekwencji w realizacji polityki antyinflacyjnej i antycyklicznej. Skutkiem antycyklicznej polityki pieniężnej sektora bankowego mogą być zmiany cech morfologicznych ogólnogospodarczego cyklu koniunkturalnego. Mogą one polegać nie tylko na skróceniu okresu trwania poszczególnych faz i całego cyklu, lecz także na zmniejszeniu amplitudy faz i cyklu oraz ich intensywności.

\subsection{Wpływ cykli koniunkturalnych na cykle w sektorze bankowym}

Ogólnogospodarcze krótko- i średniookresowe zmiany aktywności są - obok determinant wynikających z funkcjonowania systemu bankowego - drugą grupą czynników wpływających na działalność banku centralnego i banków komercyjnych. Tym samym są one czynnikiem kształtującym dynamikę podaży pieniądza oraz poziom i strukturę wielkości udzielanych kredytów, zarówno na cele inwestycyjne, jak i konsumpcyjne. Inne są bowiem decyzje sektora bankowego w warunkach fazy wysokiej dynamiki wzrostu, a inne gdy w gospodarce występuje faza recesji koniunkturalnej.

Jeśli w gospodarce występuje faza wysokiej stopy wzrostu, tj. gdy rośnie stopień wykorzystania rzeczowych i ludzkich czynników produkcji, gdy zwiększa się popyt rynkowy na dobra inwestycyjne, a w konsekwencji na dobra konsumpcyjne, może nastąpić wzrost podaży pieniądza i zwiększenie popytu na pieniądz 
banku centralnego, a tym samym na pieniądz kredytowy banków komercyjnych. Dynamika tego wzrostu może być relatywnie wysoka, zwłaszcza na początku fazy wzrostowej cyklu koniunkturalnego, niższa natomiast, gdy w gospodarce będą występowały symptomy świadczące o końcu pomyślnej koniunktury. Oznaczać to będzie osłabienie dynamiki liczby kredytów, udzielanych gospodarstwom domowym z przeznaczeniem na cele konsumpcyjne, oraz przede wszystkim zmniejszenie liczby kredytów dla przedsiębiorstw, wykorzystywanych na inwestycje. W tej fazie cyklu koniunkturalnego dynamika działalności kredytowej będzie wyższa w przypadku przedsiębiorstw niż konsumentów. Czynnikiem ograniczającym poziom i dynamikę przyznawanych przez banki komercyjne kredytów może być w tym okresie restrykcyjna i antycykliczna polityka pieniężna banku centralnego, polegająca na wzroście stóp procentowych.

Jeśli w danym systemie gospodarczym występuje faza niskiej dynamiki wzrostu, gdy stopień wykorzystania czynników produkcji spada, wówczas zmniejsza się dynamika popytu rynkowego na dobra inwestycyjne i konsumpcyjne. Zapotrzebowanie na kredyt, zwłaszcza konsumpcyjny, wskutek spadku poziomu zatrudnienia może się w niewielkim stopniu zwiększać. Banki komercyjne mogą jednak ograniczać działalność kredy tową, gdyż będzie rosło ryzyko kredytowe, związane z aktualnym i oczekiwanym spadkiem płynności wnioskodawców. Czynnikami zmniejszającymi dynamikę kredytów przeznaczonych na inwestycje może być w okresie recesji spadek dynamiki przychodów przedsiębiorstw, ograniczenie ich działalności inwestycyjnej oraz wzrost kosztów kredytów [Lubiński 2012, s. 137]. Może to doprowadzić do spadku dynamiki kredytów dla gospodarstw domowych i przedsiębiorstw, przy czym szybkość zmniejszania liczby kredytów przeznaczonych na inwestycje będzie wyższa aniżeli na konsumpcję gospodarstw domowych. W tej fazie cyklu koniunkturalnego mogą także wystąpić impulsy wynikające z prowadzonej przez bank centralny ekspansywnej polityki pieniężnej. Jej efektem może być spadek ceny pieniądza (stóp procentowych), wzrost podaży pieniądza, zwiększenie płynności banków komercyjnych oraz zmniejszenie ryzyka kredytowego, np. poprzez system zabezpieczeń kredytowych. Czynniki te mogą doprowadzić do hamowania szybkości spadku i do stopniowego nasilania się dynamiki wzrostu działalności kredytowej.

Z powyższych rozważań wynika, że zmiany aktywności gospodarczej w danym kraju mogą być czynnikiem kształtującym dynamikę działalności sektora bankowego. Cykle te będą składały się z dwóch faz: restrykcyjnej (gdy w gospodarce wystąpi pomyślna koniunktura cyklu ogólnogospodarczego) oraz ekspansywnej (podczas recesji w gospodarce). W fazie wzrostowej cyklu koniunkturalnego sektor bankowy będzie preferował działalność restrykcyjną, czyli będzie ograniczał dynamikę wzrostu podaży pieniądza, zmiany stóp procentowych będą stabilne lub rosnące, a aktywność kredytowa banków komercyjnych będzie ograniczana. Z kolei gdy w gospodarce wystąpi faza recesji cyklu ogólnogospodarczego, sektor bankowy powinien przyczynić się do powstania fazy ekspansywnej, w której będzie rosła skłon- 
ność do wzrostu podaży pieniądza na rynku, będzie następował spadek wysokości stóp procentowych oraz wzrost działalności kredytowej na inwestycje i konsumpcję. Będzie to oznaczało, że kształtowanie cykli sektora bankowego będzie asymetryczne w stosunku do przebiegu ogólnogospodarczego cyklu koniunkturalnego, przy czym długość fazy restrykcyjnej (ekspansywnej) cyklu sektora bankowego może być zbliżona lub krótsza od długości cyklu koniunkturalnego. Amplituda i intensywność faz i cyklu sektora bankowego może być niższa niż cyklu ogólnogospodarczego, gdyż dynamika wzrostu lub spadku podaży pieniądza, stóp procentowych oraz wielkości udzielanych kredytów będzie zależała od siły natężenia i kierunków działania czynników koniunkturalnych, pobudzających lub hamujących działalność banku centralnego i banków komercyjnych. W tym przypadku należy jednak pamiętać, że wahania w działalności banków będą opóźnione w stosunku do zmian ogólnogospodarczej koniunktury. Długość tego opóźnienia będzie zależała m.in. od szybkości reakcji systemu bankowego na zmiany aktywności oraz od wrażliwości poszczególnych podmiotów gospodarczych na zmiany koniunktury.

\section{Empiryczna analiza morfologii cyklu koniunkturalnego i cykli w sektorze bankowym w Polsce w latach 2000-2017}

W empirycznej analizie morfologii cyklu koniunkturalnego i cykli w sektorze bankowym w gospodarce polskiej w latach 2000-2017 wykorzystano dwie grupy danych, publikowanych od grudnia 1996 r. przez Narodowy Bank Polski². W pierwszej $\mathrm{z}$ nich występują szeregi czasowe charakteryzujące kredyty udzielane przedsiębiorstwom (stany w mln złotych). W szczególności w grupie tej można wyodrębnić: kredyty bankowe złotowe i walutowe ogółem (KBP). W grupie gospodarstw domowych występują kredyty bankowe złotowe i walutowe ogółem (KBG) ${ }^{3}$.

Ponieważ w pracy przyjęto, że cykle w sektorze bankowym to względne zmiany w działalności banku centralnego i banków komercyjnych, a jednocześnie istnieją dostępne miesięczne dane wielkości absolutnych kredytów dla przedsiębiorstw i gospodarstw domowych, ich wartości przekształcono w ten sposób, iż najpierw sprowadzono absolutne wartości miesięczne do danych kwartalnych, a w następnym etapie obliczono indeksy ich dynamiki, gdzie podstawą był analogiczny kwartał roku poprzedniego ${ }^{4}$ W tak przekształconych szeregach czasowych wyodrębniono punkty zwrotne i fazy cykli koniunkturalnych oraz cykli w sektorze bankowym.

W grupie wskaźników odzwierciedlających ogólnogospodarczy cykl koniunkturalny występują indeksy dynamiki produktu krajowego brutto, spożycia indywidualnego gospodarstw domowych oraz nakłady brutto na środki trwałe wyrażane w

2 Dane empiryczne znajdujące się w tej grupie były do lutego 2002 r. oparte na szacunkach.

3 Dynamikę działalności kredytowej banków jako miernik cykli finansowych przyjmuje w swych analizach C. Borio [2012].

${ }_{4}$ Przekształcenia te spowodowały, że analizy empiryczne cykli w sektorze bankowym rozpoczęły się w pierwszym kwartale $1998 \mathrm{r}$. 
cenach stałych (analogiczny kwartał roku poprzedniego $=100)^{5}$. Szeregi te zostały oszacowane $\mathrm{w}$ cenach stałych, przy czym deflatorem były indeksy dynamiki cen dóbr i usług konsumpcyjnych w gospodarce polskiej.

\subsection{Metodyka prac empirycznych}

Zgodnie z występującą w literaturze interpretacją ogólnogospodarczych cykli koniunkturalnych przyjęto, że głównymi elementami budowy tych cykli i cykli w sektorze bankowym są punkty zwrotne i fazy. Wyodrębniono dwa punkty zwrotne: górny i dolny, przy czym zwrot górny (dolny) występuje, gdy wartość odchylenia elementów szeregu czasowego od oszacowanego trendu jest maksymalna (minimalna). W cyklu koniunkturalnym wyróżniono dwie fazy: wzrostową (między punktem zwrotnym dolnym i górnym) oraz spadkową (między zwrotem górnym i dolnym). W cyklu bankowym występują także dwie fazy: ekspansywna i restrykcyjna.

W procesie wyodrębniania analizowanych cykli przyjęto koncepcję cykli odchyleń, znaną z koniunktury gospodarczej. Zgodnie z tą procedurą pierwszy etap wyodrębniania cyklu polega na eliminacji z analizowanych szeregów czasowych wahań sezonowych i przypadkowych. Desezonalizację przeprowadzono poprzez zastosowanie procedury Tramo/Seats w ramach pakietu Demetra 2.0. Metoda ta, zalecana przez Eurostat i stosowana przez GUS, polega na eliminacji z badanych szeregów czasowych efektu zmienności kalendarzowej, zmienności dni roboczych oraz czynników sezonowych. Jej istotą jest wygładzenie szeregu czasowego wielokrotnie dobieranymi średnimi ruchomymi [Grudkowska, Paśnicka 2007, s. 15-16]. Do dalszej analizy przyjęto szeregi, które zawierały łączne działanie trendu i wahań cyklicznych.

Kolejny etap w procesie wyodrębniania badanych cykli polegał na oszacowaniu w przyjętych szeregach czasowych tendencji rozwojowej. W tym przypadku głównym problemem był dobór funkcji trendu, który bardzo często determinuje usytuowanie punktów zwrotnych i przebieg faz [Tichy 1976, s. 48]. W tej sytuacji w analizie wykorzystano metodę statystyczną zakładającą, że składnik cykliczny danej zmiennej jest różnicą między jej wartością empiryczną a wartością trendu, która jest ważona średnią przeszłych, obecnych i przyszłych obserwacji. Metoda ta jest określana jako filtr Hodricka-Prescotta, a w jej wyniku otrzymano wartości pokazujące długookresową tendencję rozwojową, która nie jest funkcją deterministyczną, lecz sama podlega zmianom w czasie [Prescott 1986, s. 10]. Wyznaczony w ten sposób trend jest niezależny od komponentu cyklicznego.

W następnym etapie prac zmiany wartości badanych wskaźników, przedstawiające elementy cykliczne, otrzymano w ten sposób, że odjęto od wartości elementów szeregów, z których wyeliminowano zmiany sezonowe i losowe, wartości trendu, oszacowane wskutek zastosowania filtra Hodricka-Prescotta.

5 W tej grupie danych analizę cykli koniunkturalnych rozpoczęto w pierwszym kwartale 2000 r., co było spowodowane dostępem do kwartalnych wartości PKB w tym okresie. 


\subsection{Cechy morfologiczne cykli koniunkturalnych i cykli w sektorze bankowym}

W analizach empirycznych cykli koniunkturalnych i cykli występujących w sektorze bankowym badano ich morfologię [Barczyk, Kowalczyk 1993, s. 189-28]. Oznacza to, że analizowano elementy budowy obu grup cykli, przyjmując, że składają się one z dwóch elementów: punktów zwrotnych i faz. W obu przypadkach przyjęto, że punkt zwrotny górny występuje, gdy wartości przyjętego szeregu osiągają maksimum (punkt zwrotny górny) lub minimum (punkt zwrotny dolny). Zgodnie z koncepcją współczesnych cykli założono, że cykle te składają się jedynie z dwóch faz. W cyklach koniunkturalnych była to faza wysokiej dynamiki wzrostu (faza wzrostowa), która występuje między punktem zwrotnym dolnym i górnym, przy czym kwartał, w którym odchylenie od trendu było maksymalne (minimalne), był wliczany do długości fazy wzrostowej (spadkowej). W cyklach istniejących w sektorze bankowym przyjęto także występowanie dwóch faz: restrykcyjnej i ekspansywnej, a określenia te są bezpośrednią konsekwencją charakteru stosowanej antycyklicznej polityki pieniężnej. Faza restrykcyjna miała miejsce w okresie, gdy wartości szeregów czasowych były odpowiednio maksymalne i minimalne, przy czym kwartał, gdy były one minimalne, był wliczony do długości tej fazy. Faza ekspansywna występuje, gdy wartości analizowanych danych były malejące, czyli w okresie między punktem zwrotnym górnym i dolnym. Wśród cech morfologicznych badano długość (w kwartałach) poszczególnych faz i cykli, zakładając, że minimalna długość fazy wynosi trzy kwartały. Kolejną analizowaną cechą morfologiczną była amplituda faz i cykli, przy czym amplituda fazy wzrostowej cyklu koniunkturalnego (fazy restrykcyjnej cyklu w sektorze bankowym) była szacowana jako suma wartości bezwzględnych szeregu odchyleń w punkcie zwrotnym górnym i dolnym. W fazie spadkowej cyklu koniunkturalnego lub w fazie ekspansji cyklu w sektorze bankowym ich amplituda była równa sumie wartości bezwzględnych odpowiednio w punkcie zwrotnym dolnym i górnym. Amplituda cykli była równa różnicy między amplitudą fazy wzrostowej (restrykcyjnej) i spadkowej (ekspansywnej). Wartości charakteryzujące badane cechy morfologiczne obu grup cykli zostały zestawione w tabelach 1 i 2.

$\mathrm{Z}$ wartości charakteryzujących cechy morfologiczne cykli koniunkturalnych występujących w Polsce w latach 2000-2017, wyodrębnionych w zdeflatowanym szeregu PKB, wynika, że w tym czasie wyróżniono 8 faz (w tym cztery wzrostowe i cztery spadkowe). Utworzyły one cztery pełne cykle koniunkturalne, a ich długość wynosiła od 3,5 do 4,5 roku, przy czym w dwóch przypadkach faza wzrostowa była dłuższa niż spadkowa, a w pozostałych sytuacjach okres trwania fazy spadkowej był nieco dłuższy aniżeli wzrostowej. Amplitudy faz przyjmowały niewysokie wartości dodatnie, a amplituda cykli w trzech przypadkach była dodatnia. Jedynie w cyklu występującym od czwartego kwartału 2000 r. do pierwszego kwartału 2005 r. amplituda była ujemna. Takie wartości amplitudy cykli koniunkturalnych mogą do- 
wodzić, że w okresie długim w gospodarce naszego kraju występowały procesy wzrostu gospodarczego.

Tabela 1. Wybrane cechy morfologiczne cykli koniunkturalnych występujących w PKB, spożyciu indywidualnym i nakładach brutto (w cenach stałych) w Polsce w latach 2000-2017

\begin{tabular}{|c|c|c|c|c|c|c|c|c|}
\hline \multirow{2}{*}{$\begin{array}{l}\text { Cechy } \\
\text { cykli }\end{array}$} & \multicolumn{2}{|c|}{ Fazy cykli } & \multicolumn{2}{|c|}{ Fazy cykli } & \multicolumn{2}{|c|}{ Fazy cykli } & \multicolumn{2}{|c|}{ Fazy cykli } \\
\hline & $\begin{array}{c}\text { wzros- } \\
\text { towa }\end{array}$ & $\begin{array}{l}\text { spad- } \\
\text { kowa }\end{array}$ & $\begin{array}{c}\text { wzros- } \\
\text { towa }\end{array}$ & spadkowa & $\begin{array}{c}\text { wzros- } \\
\text { towa }\end{array}$ & $\begin{array}{l}\text { spad- } \\
\text { kowa }\end{array}$ & $\begin{array}{c}\text { wzros- } \\
\text { towa }\end{array}$ & spadkowa \\
\hline \multicolumn{9}{|c|}{ Produkt krajowy brutto } \\
\hline $\begin{array}{c}\text { Okresy } \\
\text { występo- } \\
\text { wania }\end{array}$ & $\begin{array}{l}\text { IV kw. } \\
2000- \\
\text {-II kw. } \\
2003\end{array}$ & $\begin{array}{c}\text { III kw. } \\
2003- \\
-I \text { kw. } \\
2005\end{array}$ & $\begin{array}{l}\text { II kw. } \\
2005- \\
\text {-III kw. } \\
2006\end{array}$ & $\begin{array}{l}\text { IV kw. } \\
2006- \\
\text {-II kw. } \\
2009\end{array}$ & $\begin{array}{l}\text { III kw. } \\
2009- \\
\text {-III kw. } \\
2010\end{array}$ & $\begin{array}{l}\text { IV kw. } \\
2010- \\
\text {-III kw. } \\
2012\end{array}$ & $\begin{array}{c}\text { IV kw. } \\
2012- \\
-\mathrm{I} \mathrm{kw.} \\
2015\end{array}$ & $\begin{array}{l}\text { II kw. } \\
2015- \\
\text {-I kw. } \\
2017\end{array}$ \\
\hline \multicolumn{9}{|l|}{ Długość } \\
\hline - faz & 11 & 7 & 6 & 11 & 5 & 8 & 10 & 8 \\
\hline - cykli & \multicolumn{2}{|c|}{18} & \multicolumn{2}{|c|}{17} & \multicolumn{2}{|c|}{13} & \multicolumn{2}{|c|}{18} \\
\hline \multicolumn{9}{|l|}{ Amplituda } \\
\hline - faz & 4,87 & 6,31 & 6,56 & 6,54 & 5,16 & 4,59 & 5,34 & 3,99 \\
\hline - cykli & \multicolumn{2}{|c|}{$-1,45$} & \multicolumn{2}{|c|}{0,02} & \multicolumn{2}{|c|}{0,57} & \multicolumn{2}{|c|}{1,35} \\
\hline \multicolumn{9}{|c|}{ Spożycie indywidualne } \\
\hline $\begin{array}{c}\text { Okresy } \\
\text { występo- } \\
\text { wania }\end{array}$ & $\begin{array}{l}\text { III kw. } \\
2000- \\
\text {-III kw. } \\
2002\end{array}$ & $\begin{array}{c}\text { IV kw. } \\
2002- \\
\text {-IV kw. } \\
2004\end{array}$ & $\begin{array}{c}\text { I kw. } \\
2005- \\
\text {-II kw. } \\
2006\end{array}$ & $\begin{array}{l}\text { III kw. } \\
2006- \\
\text {-III kw. } \\
2009\end{array}$ & $\begin{array}{l}\text { IV kw. } \\
2009- \\
\text {-III kw. } \\
2010\end{array}$ & $\begin{array}{c}\text { IV kw. } \\
2010- \\
\text {-III kw. } \\
2012\end{array}$ & $\begin{array}{c}\text { IV kw. } \\
2012- \\
-\mathrm{I} \mathrm{kw.} \\
2015\end{array}$ & $\begin{array}{c}\text { II kw. } \\
2015- \\
\text {-III kw. } \\
2017\end{array}$ \\
\hline \multicolumn{9}{|l|}{ Długość } \\
\hline - faz & 9 & 9 & 6 & 13 & 4 & 8 & 10 & 10 \\
\hline - cykli & \multicolumn{2}{|c|}{18} & \multicolumn{2}{|c|}{19} & \multicolumn{2}{|c|}{12} & \multicolumn{2}{|c|}{20} \\
\hline \multicolumn{9}{|l|}{ Amplituda } \\
\hline - faz & 5,72 & 5,98 & 6,19 & 4,20 & 3,65 & 4,96 & 4,89 & 3,66 \\
\hline - cykli & \multicolumn{2}{|c|}{$-0,26$} & \multicolumn{2}{|c|}{1,99} & \multicolumn{2}{|c|}{$-1,31$} & \multicolumn{2}{|c|}{1,23} \\
\hline \multicolumn{9}{|c|}{ Nakłady brutto } \\
\hline $\begin{array}{c}\text { Okresy } \\
\text { występo- } \\
\text { wania }\end{array}$ & $\begin{array}{l}\text { IV kw. } \\
2001- \\
\text {-III kw. } \\
2003\end{array}$ & $\begin{array}{c}\text { IV kw. } \\
2003- \\
-I \text { kw. } \\
2005\end{array}$ & $\begin{array}{l}\text { II kw. } \\
2005- \\
-I I \text { kw. } \\
2007\end{array}$ & $\begin{array}{l}\text { III kw. } \\
2007- \\
\text {-IV kw. } \\
2008\end{array}$ & $\begin{array}{l}\text { I kw. } \\
2009- \\
-\mathrm{I} \mathrm{kw.} \\
2011\end{array}$ & $\begin{array}{c}\text { II kw. } \\
2011- \\
\text {-II kw. } \\
2012\end{array}$ & $\begin{array}{c}\text { III kw. } \\
2012- \\
\text {-IV kw. } \\
2014\end{array}$ & $\begin{array}{c}\text { I kw. } \\
2015- \\
\text {-IV kw. } \\
2016\end{array}$ \\
\hline \multicolumn{9}{|l|}{ Długość } \\
\hline - faz & 8 & 6 & 9 & 6 & 9 & 5 & 7 & 8 \\
\hline - cykli & \multicolumn{2}{|c|}{14} & \multicolumn{2}{|c|}{15} & \multicolumn{2}{|c|}{14} & & 5 \\
\hline Amplituda & & & & & & & & \\
\hline - faz & 9,28 & 5,05 & 14,59 & 18,74 & 12,42 & 16,45 & 19,27 & 11,79 \\
\hline - cykli & 4, & & & 15 & -4 & & & 48 \\
\hline
\end{tabular}

Źródło: obliczenia własne. 
Morfologia cykli koniunkturalnych i cykli bankowych w gospodarce polskiej...

Tabela 2. Wybrane cechy morfologiczne cykli w sektorze bankowym w Polsce w latach 2000-2017

\begin{tabular}{|c|c|c|c|c|c|c|c|c|c|c|}
\hline \multirow{2}{*}{$\begin{array}{l}\text { Cechy } \\
\text { cykli }\end{array}$} & \multicolumn{2}{|c|}{ Fazy cykli } & \multicolumn{2}{|c|}{ Fazy cykli } & \multicolumn{2}{|c|}{ Fazy cykli } & \multicolumn{2}{|c|}{ Fazy cykli } & \multicolumn{2}{|c|}{ Fazy cykli } \\
\hline & $\begin{array}{c}\text { restryk- } \\
\text { cyjna }\end{array}$ & $\begin{array}{c}\text { ekspan- } \\
\text { sywna }\end{array}$ & $\begin{array}{c}\text { restryk- } \\
\text { cyjna }\end{array}$ & $\begin{array}{l}\text { ekspan- } \\
\text { sywna }\end{array}$ & $\begin{array}{c}\text { restryk- } \\
\text { cyjna }\end{array}$ & $\begin{array}{c}\text { ekspan- } \\
\text { sywna }\end{array}$ & $\begin{array}{c}\text { restryk- } \\
\text { cyjna }\end{array}$ & $\begin{array}{c}\text { ekspan- } \\
\text { sywna }\end{array}$ & $\begin{array}{c}\text { restryk- } \\
\text { cyjna }\end{array}$ & $\begin{array}{l}\text { ekspan- } \\
\text { sywna }\end{array}$ \\
\hline \multicolumn{11}{|c|}{ Agregat $\mathrm{M}_{1}$} \\
\hline $\begin{array}{c}\text { Okresy } \\
\text { wystę- } \\
\text { powa- } \\
\text { nia }\end{array}$ & $\begin{array}{c}\text { I kw. } \\
2001- \\
\text {-II kw. } \\
2002\end{array}$ & $\begin{array}{c}\text { III kw. } \\
2002- \\
\text {-IV kw. } \\
2004\end{array}$ & $\begin{array}{l}\text { I kw. } \\
2005- \\
\text {-I kw. } \\
2007\end{array}$ & $\begin{array}{c}\text { II kw. } \\
2007- \\
\text {-I kw. } \\
2009\end{array}$ & $\begin{array}{c}\text { II kw. } \\
2009- \\
\text {-IV kw. } \\
2010\end{array}$ & $\begin{array}{l}\text { I kw. } \\
2011- \\
\text {-I kw. } \\
2012 \\
\end{array}$ & $\begin{array}{c}\text { II kw. } \\
2012- \\
\text {-IV kw. } \\
2013\end{array}$ & $\begin{array}{c}\text { I kw. } \\
2014- \\
\text { III kw. } \\
2014\end{array}$ & $\begin{array}{c}\text { IV kw. } \\
2014- \\
\text {-IV kw. } \\
2016\end{array}$ & $\begin{array}{l}\text { I kw. } \\
2017-\end{array}$ \\
\hline \multicolumn{11}{|l|}{ Długość } \\
\hline - faz & 6 & 10 & 9 & 8 & 7 & 5 & 7 & 3 & 9 & \\
\hline - cykli & \multicolumn{2}{|c|}{16} & \multicolumn{2}{|c|}{17} & \multicolumn{2}{|c|}{12} & \multicolumn{2}{|c|}{$\frac{1}{10}$} & & \\
\hline \multicolumn{11}{|c|}{ Amplituda } \\
\hline - faz & 26,37 & 21,77 & 22,12 & 24,05 & 14,39 & 12,86 & 13,41 & 8,43 & & \\
\hline - cykli & \multicolumn{2}{|c|}{4,6} & \multicolumn{2}{|c|}{$-1,93$} & \multicolumn{2}{|c|}{1,53} & \multicolumn{2}{|c|}{4,98} & & \\
\hline \multicolumn{11}{|c|}{ Agregat $\mathrm{M}_{2}$} \\
\hline $\begin{array}{l}\text { Okresy } \\
\text { wystę- } \\
\text { powa- } \\
\text { nia }\end{array}$ & & $\begin{array}{c}\text { II } \\
\text { kw.2002- } \\
\text {-IV kw. } \\
2002\end{array}$ & $\begin{array}{l}\text { I kw. } \\
2003- \\
\text {-I kw. } \\
2007\end{array}$ & $\begin{array}{c}\text { II kw. } \\
2007- \\
\text {-III kw. } \\
2010\end{array}$ & $\begin{array}{c}\text { IV kw. } \\
2010-\mathrm{I} \\
\text { kw. } \\
2012\end{array}$ & $\begin{array}{c}\text { II kw. } \\
2012- \\
\text {-IV kw. } \\
2012\end{array}$ & $\begin{array}{l}\text { I kw. } \\
2013- \\
\text { II kw. } \\
2016\end{array}$ & $\begin{array}{l}\text { III kw. } \\
\text { 2016- }\end{array}$ & & \\
\hline \multicolumn{11}{|l|}{ Długość } \\
\hline - faz & & 11 & 13 & 14 & 6 & 3 & 16 & & & \\
\hline - cykli & & & \multicolumn{2}{|c|}{27} & \multicolumn{2}{|c|}{9} & & & & \\
\hline \multicolumn{11}{|c|}{ Amplituda } \\
\hline - faz & & 13,96 & 15,52 & 9,66 & 3,63 & 3,41 & 5,54 & & & \\
\hline - cykli & & & \multicolumn{2}{|c|}{5,86} & \multicolumn{2}{|c|}{0,22} & & & & \\
\hline \multicolumn{11}{|c|}{ Kredyty bankowe dla przedsiębiorstw niefinansowych } \\
\hline $\begin{array}{c}\text { Okresy } \\
\text { wystę- } \\
\text { powa- } \\
\text { nia }\end{array}$ & & $\begin{array}{l}\text { II kw. } \\
2000- \\
\text {-II kw. } \\
2002 \\
\end{array}$ & $\begin{array}{c}\text { III kw. } \\
2002- \\
\text {-II kw. } \\
2003\end{array}$ & $\begin{array}{c}\text { III kw. } \\
2003- \\
\text {-IV kw. } \\
2004\end{array}$ & $\begin{array}{c}\text { I kw. } \\
2005- \\
\text {-IV kw. } \\
2008\end{array}$ & $\begin{array}{c}\text { I kw. } \\
2009- \\
\text {-I kw. } \\
2010\end{array}$ & $\begin{array}{l}\text { II kw. } \\
2010- \\
\text {-I kw. } \\
2012\end{array}$ & $\begin{array}{c}\text { II kw. } \\
2012- \\
\text {-III kw. } \\
2013\end{array}$ & $\begin{array}{c}\text { IV kw. } \\
2013- \\
\text {-I kw. } \\
2016\end{array}$ & $\begin{array}{l}\text { II kw. } \\
2016- \\
\text {-I kw. } \\
2017\end{array}$ \\
\hline \multicolumn{11}{|l|}{ Długość } \\
\hline - faz & & 9 & 4 & 6 & 16 & 5 & 8 & 7 & 10 & 4 \\
\hline - cykli & & & \multicolumn{2}{|c|}{10} & & & & & & \\
\hline Amplitu & & & & & & & & & & \\
\hline - faz & & 9,45 & 4,74 & 8,72 & 23,40 & 31,56 & 25,87 & 14,43 & 9,48 & 6,08 \\
\hline - cykli & & & & & & & & & & \\
\hline & & & Kredy & bankow & dla gosp & darstw do & howych & & & \\
\hline $\begin{array}{c}\text { Okresy } \\
\text { wystę- } \\
\text { powa- } \\
\text { nia }\end{array}$ & & $\begin{array}{c}\text { II kw. } \\
2000- \\
\text {-IV kw. } \\
2002\end{array}$ & $\begin{array}{l}\text { I kw. } \\
2003- \\
\text {-I kw. } \\
2009\end{array}$ & $\begin{array}{c}\text { II kw. } \\
2009- \\
\text {-I kw. } \\
2010\end{array}$ & $\begin{array}{c}\text { II kw. } \\
2010- \\
\text {-II kw. } \\
2015\end{array}$ & $\begin{array}{l}\text { III kw. } \\
2015-\end{array}$ & & & & \\
\hline Długość & & & & & & & & & & \\
\hline - faz & & 10 & 25 & 4 & 21 & & & & & \\
\hline - cykli & & & & & & & & & & \\
\hline Amplitu & & & & & & & & & & \\
\hline - faz & & 21,68 & 25,04 & 28,65 & 15,65 & & & & & \\
\hline - cykli & & & -3 & & & & & & & \\
\hline
\end{tabular}

Źródło: obliczenia własne. 
Drugi przyjęty szereg czasowy ukazuje fluktuacje występujące w spożyciu indywidualnym gospodarstw domowych. W tym przypadku wyodrębniono także 8 faz (w tym cztery wzrostowe i cztery spadkowe), które również utworzyły cztery cykle koniunkturalne. Długość faz spadkowych w dwóch sytuacjach była dłuższa niż faz wzrostowych, a w pozostałych cyklach były one równe i wynosiły od dwóch do trzech lat. Oszacowane amplitudy faz były dodatnie i zbliżone do występujących w oscylacjach PKB, a ponadto amplitudy cykli były relatywnie niskie i w dwóch przypadkach były ujemne, a w pozostałych dodatnie. Najwyższa wartość ujemna amplitudy cyklu wystąpiła podczas światowego kryzysu finansowego.

Kolejny analizowany szereg czasowy przedstawia oscylacje koniunkturalne występujące w nakładach brutto na środki trwałe. Także w tym przypadku, podobnie jak poprzednio, wyodrębniono 8 faz (cztery wzrostowe i cztery spadkowe), które utworzyły cztery pełne cykle koniunkturalne. Ich długość wynosiła ok. 3,5-4,0 lata, a fazy wzrostowe były nieco dłuższe niż spadkowe. Wniosek ten nie dotyczy ostatniego cyklu, lat 2012-2016. Kolejna uwaga jest związana z amplitudą faz, która była wyższa niż w szeregach PKB i spożycia indywidualnego gospodarstw domowych. Wyższe były także amplitudy cykli wyodrębnionych w nakładach brutto, a ponadto w dwóch cyklach były one ujemne, a w pozostałych cyklach dodatnie. Może to dowodzić, że w okresie długim dynamika tych nakładów była niższa niż szybkość przyrostu PKB.

Reasumując tę część analiz, można stwierdzić, że morfologia cykli koniunkturalnych, wyodrębnionych w PKB i jego elementach składowych, była podobna, a cykle te trwały ok. 3,5-4,5 roku, przy czym fazy wzrostowe były nieco dłuższe niż spadkowe. Wyższą wrażliwość koniunkturalną, tj. wyższą amplitudę wahań, wykazywały nakłady brutto na środki trwałe niż spożycie indywidualne gospodarstw domowych.

Cykle występujące w sektorze bankowym badano w dwóch grupach danych. Pierwsza pokazywała efekty działania banku centralnego, który kształtował podażowe agregaty pieniężne $\mathrm{M}_{1} \mathrm{i}_{\mathrm{M}_{2}}$. Druga przedstawiała działalność kredytową banków komercyjnych, skierowaną do przedsiębiorstw niefinansowych lub do gospodarstw domowych. Badając oscylacje występujące w agregacie $\mathrm{M}_{1}$, można było stwierdzić występowanie 9 faz (w tym 5 restrykcyjnych i 4 ekspansywne). Ich długość wynosiła od 3 do 10 kwartałów, a nieco częściej okres frazy restrykcyjnej był dłuższy niż fazy ekspansywnej. Mogło to być spowodowane tym, że głównym celem banku centralnego była chęć ograniczenia zjawisk inflacyjnych poprzez realizację polityki restrykcyjnej. Amplituda faz cykli występujących w kategorii $\mathrm{M}_{1}$ była relatywnie wyraźna, a amplituda cykli na ogół dodatnia (z wyjątkiem cyklu lat 2005-2009).

Drugi podażowy agregat pieniężny $\mathrm{M}_{2}$, kształtowany przez bank centralny, wskazuje, że liczba wyodrębnionych faz wynosiła 6 (w tym trzy restrykcyjne, a trzy ekspansywne). Fazy te umożliwiały wyróżnienie jedynie dwóch pełnych cykli. Długość faz tych cykli była dłuższa - kilkanaście kwartałów (z wyjątkiem cyklu 
lat 2010-2012, którego długość wynosiła ok. dwóch lat). W tym przypadku trudno jednoznacznie oszacować relacje między długością fazy restrykcyjnej i ekspansywnej. Można sądzić, że amplituda fazy występującej w tej kategorii była nieco niższa niż wartość tej cechy w kategorii $\mathrm{M}_{1}$ (uwaga ta nie dotyczy cyklu lat 2003-2010).

Oscylacje w działalności kredytowej dla przedsiębiorstw niefinansowych były generalnie krótsze, gdyż wynosiły od jednego do dwóch lat (z wyjątkiem fazy restrykcyjnej lat 2005-2008, występującej w okresie światowego kryzysu finansowego, która trwała cztery lata). Oznacza to, że w omawianym szeregu wyodrębniono aż 9 faz, wśród których pięć miało charakter ekspansywny, a cztery restrykcyjny. Fazy te utworzyły cztery pełne cykle sektora bankowego. Ich amplitudy były wyraźnie, najwyższe w okresie światowego kryzysu finansowego i w czasie zwalczania jego konsekwencji, przy czym w dwóch pierwszych cyklach amplitudy były ujemne, a w dwóch kolejnych dodatnie.

Ostatni analizowany szereg czasowy przedstawia fluktuacje kredytów bankowych dla gospodarstw domowych. W tej sytuacji można było wyodrębnić jedynie cztery fazy i jeden pełny cykl. Fazy te były stosunkowo długie, od dwóch do sześciu lat (wyjątkiem jest faza lat 2009-2010). W tym przypadku także można stwierdzić, że średnia długość fazy restrykcyjnej była dłuższa niż fazy ekspansywnej. Relatywnie wysokie były amplitudy faz (wyższe niż oscylacji kredytów dla instytucji niefinansowych), a amplituda cyklu lat 2003-2010 była ujemna.

Podsumowując analizowane cechy morfologiczne cykli istniejących w sektorze bankowym, stwierdzono, że w szeregach czasowych występowały relatywnie wyraźne oscylacje, a najbardziej wrażliwe były: agregat pieniężny $M_{1} i$ kredyty bankowe dla instytucji niefinansowych (liczba wyodrębnionych faz i cykli była najwyższa). Dłuższe fazy i cykle występowały w działalności kredytowej dla gospodarstw domowych niż dla instytucji niefinansowych. Cykle wyodrębnione w sektorze bankowym wykazywały relatywnie wysokie amplitudy, przy czym często amplituda fazy restrykcyjnej była wyższa niż w okresach ekspansji. Może to dowodzić, że w polskiej polityce pieniężnej dominowały działania antyinflacyjne, a mniejszą rolę odgrywała polityka antycykliczna.

Analizując cechy morfologiczne cykli koniunkturalnych i cykli występujących w sektorze bankowym, trudno w jednoznaczny sposób ocenić okresy odroczeń czasowych występowania punktów zwrotnych, tj. trudno oszacować wartość współczynników korelacji wielorakiej między zmianami poszczególnych danych i ustalić, kiedy wartości te były najwyższe. Spowodowane to było przez fakt, że w szeregach charakteryzujących analizowane cykle zmienne te w wysokim stopniu wykazywały wysoką współzmienność. W tej sytuacji podjęto jedynie próbę analizy graficznej okresów wyprzedzeń i opóźnień czasowych między poszczególnymi zwrotami. Na tej podstawie stwierdzono, że punkty zwrotne w sektorze bankowym często tworzyły fazy, które miały charakter działań antycyklicznych w stosunku do fluktuacji występujących w PKB. Oznacza to, że działania restrykcyjne współwystępowały z fazą wzrostu cyklu koniunkturalnego, a pieniężna polityka ekspansywna była pro- 
wadzona w okresie fazy spadkowej. Jednoznaczne określenie (w kwartałach) okresów wyprzedzeń lub opóźnień występowania punktów zwrotnych analizowanych cykli okazało się niestety niemożliwe.

\section{Zakończenie}

Teoretyczne i empiryczne analizy zmian aktywności gospodarczej i prowadzonej w gospodarce polskiej w latach 2000-2017 pieniężnej polityki stabilizacji makroekonomicznej wskazują, że występowały nie tylko cykle koniunkturalne, lecz także powiązane z nimi cykle w sektorze bankowym. Geneza tych cykli wynika z prowadzonej w naszym kraju restrykcyjnej lub ekspansywnej polityki pieniężnej.

Cykle koniunkturalne w gospodarce polskiej posiadają cechy morfologiczne typowe dla współczesnych gospodarek rynkowych. Są one zbudowane z dwóch faz: wysokiej lub niskiej dynamiki wzrostu, przy czym fazy pomyślnej koniunktury często są dłuższe aniżeli okresy spadku, a całe cykle są stosunkowo krótkie. Amplitudy tych cykli są relatywnie małe i dodatnie, co wskazuje na istniejące procesy wzrostu gospodarczego.

Cykle występujące w sektorze bankowym są konsekwencją nie tylko polityki banku centralnego czy działalności banków komercyjnych. Szczególnie wrażliwe na fluktuację są szeregi agregatu pieniężnego $\mathrm{M}_{1} \mathrm{i}$ kredyty udzielane instytucjom niefinansowym. Cykle te składają się z dwóch faz (restrykcyjnej i ekspansywnej), a ich kształtowanie zależy od charakteru prowadzonej pieniężnej polityki antycyklicznej, tj. faza restrykcyjna (ekspansywna) współwystępuje z fazą wzrostową (spadkową) cyklu koniunkturalnego. Niestety, na podstawie prac empirycznych nie udało się, ze względów formalnych, ustalić relacji czasowej (okresów odroczeń lub wyprzedzeń czasowych) między punktami zwrotnymi wyodrębnionymi w badanych cyklach. Mogło to być powodowane tym, że działanie narzędzi polityki pieniężnej jest determinowane przez czynniki koniunkturalne, a także np. przez procesy inflacyjne.

\section{Literatura}

Barczyk R., 2014, Źródła i morfologia cykli kredytowych w Polsce w latach 1998-2013, Studia i Prace Wydziału Nauk Ekonomicznych i Zarządzania, nr 35, t. 2, Wydawnictwo Uniwersytetu Szczecińskiego, Szczecin.

Barczyk R., Kowalczyk Z., 1993, Metody badania koniunktury gospodarczej, Wydawnictwo Naukowe PWN, Warszawa-Poznań.

Borio C., 2012, The Financial Cycle and Macroeconomics: What Have We Learnt?, BIS Working Papers, no. 395 .

Grudkowska S., Paśnicka E., 2007, X-12-Arima i Tramo/Seats - empiryczne porównanie metod wyrównywania sezonowego w kontekście dlugości próby, Materiały i Studia, z. 20, NBP, Warszawa. Jarchow H.-J., 1995, Theorie und Politik des Geldes. II Geldpolitik, Springer Verlag, Göttingen. 
Jaworski W.J., Krzyżkiewicz Z.G., Kosiński B., 1998, Banki, Rynek Operacje, Polityka, Poltext, Warszawa.

Kaźmierczak A., 2012, Polityka pieniężna w gospodarce otwartej, Wydawnictwo Naukowe PWN, Warszawa.

Lubiński M., 2012, Aktywność kredytowa banków w cyklu koniunkturalnym, [w:] K. Walczyk (red.), Badanie koniunktury - zwierciadło gospodarki, SGH, Warszawa.

Małecki W., 2014, Przeciwdziałanie procykliczności sektora bankowego, Gospodarka Narodowa, nr 4, SGH, Warszawa.

Prescott E.C., 1986, Theory Ahead Business Cycle Measurement, Federal Reserve Bank of Minneapolis Quarterly Review, Minneapolis.

Tichy G.J., 1976, Konjunkturschwankungen. Theorie, Messung, Prognose, Springer Verlag, BerlinHeidelberg-New York, vol. 16, no. 3, s. 65-76. 